\title{
ANALYSIS OF CHANGES IN PROPERTY BY USING GIS AND REGRESSION MODELS IN URBAN REGENERATION PROJECTS
}

DOI: http://dx.doi.org/10.18509/GBP.2017.12

UDC: 528.28:004]:349.4

\author{
Cankut Dağdal İnce \\ Burcu Aslan \\ Kocaeli University, Turkey
}

\begin{abstract}
In Turkey, the need for housing has increased due to migration from rural to urban areas and rapid population growth. Problems such as squatting, environmental degradation and inadequacy of infrastructure have emerged as a result of rapid urbanization. In addition, after the Marmara earthquake in 1999, the concept of urban transformation has become the main topic because of urban renewal and the need for durable housing. Within the context of urban transformation projects, reorganization of the land, relations and analysis between public improvements and property have gained importance. Geographic Information System is one of the most important and necessary methods that enable the regeneration process to be better managed.

In this study, Kocaeli where was the most of the earthquake effects is selected and the urban regeneration project applied to Erenler Cedit Settlement of Izmit district is taken as a case. An analyzable relational database is composed with GIS then mentioned data is compared with property information. As a result of the urban transformation, the changes in property are examined. The relationship between the land quantities and the sales or exchange tendencies is revealed by using Regression Analysis. Linear, logarithmic and quadratic regression models have been tested and it has been decided that the most appropriate model is linear regression model. Results are presented and the reasons are discussed.
\end{abstract}

Keywords: GIS, Property, Urban Regeneration, Regression Analysis, Correlation.

\section{INTRODUCTION}

Urban areas are complex and dynamic systems. Cities play also a major role in the changes and transformation of many such issues in addition to reflecting the effects of physical, social, environmental and economic changes [1]. It is inevitable that cities need to transform themselves for many reasons such as technological developments and changing needs over time, social events and disasters. The idea of urban transformation first emerged in the 19th century as a result of the urban growth movements in Europe. Some regions were demolished and rebuilt. After the Industrial Revolution, many philosopher and planners were affected by the bad conditions of the proletariat in the major cities of Europe and accelerated the emergence of the idea of first urban transformation [2].

Urbanization movements in Turkey accelerated as a result of immigration from villages which grew rapidly in the 1950s, and the first steps of unplanned construction has been taken in cities which are not ready for this density. While the demand for the industrial sector increased, agricultural and farming activities declined in these periods. As a consequence of the mechanization of agriculture, decrease in the demand for manpower 
increased immigration to cities and due to this situation squatters have occurred [2]. For these reasons, urban areas need to be transformed and renewed.

There are many different definitions of urban transformation according to their purposes or methods. In general terms, urban transformation is all of the strategies and actions which are implemented to improve the social, physical, environmental and economic conditions of the collapsed and degraded urban area in a comprehensive and integrated manner [3]. The concept of private property is defined in dictionaries as the ownership of movable, immovable material or intellectual possessions that real or legal persons may use in accordance with legal boundaries. Property is both a means of providing human needs and influencing people's social relations with each other and having a key role and influence in political system discussions. This situation has made it very complicated to reach easy and simple solutions to property issues. [4] [5]. The property rights in Turkish Constitution are defined in such a way that the goods and land can be used in a way that is useful to social needs and not contradictory to society [4]. In the case of a restriction on the use of the property rights, this restriction can be only regulated in the circumstances required by public welfare by law. Although the primary purpose of the urban transformation projects is the public benefit, the most important thing to pay attention is the protection of the property rights of the people [6]. Therefore it is very important to negotiate with the participation of the owners during the implementation of the projects for the protection of the property rights [7].

Many data which are related to each other and the land, such as plans, ownership information and infrastructure should be collected and analysed in order to make appropriate decisions during an urban transformation process. Thus, effective use of Geographic Information Systems is important and necessary for urban transformation projects.

Geographic Information Systems are advanced systems which are used for the collection, validation, storage of the data of geographical objects, database operations of these, queries, transformations, analyses, geographic information transformation and display of geographic data information [8].

There are many differently designed database management systems, but generally relational database systems are the most useful for geographic information systems. In this system, the data are stored in the computer memory according to the data obtained from the table information. The tables with different data are associated with each other by using common columns. This approach is simple but flexible and is used often in Geographic Information System projects [9].

In this study, Kocaeli where housing and urban transformation projects increased after Marmara Earthquake (Gölcük, 1999) is selected. A relational database is created by using property data of the sample area Erenler Cedit Urban Transformation Project and acreage data of the parcels. Trends of the owners to exchange or sale are examined with various queries. ArcMap (10.1) is used as the GIS software in the study. The relationship between the land quantities and the sales or exchange tendencies is revealed by using Regression Analysis. Linear, logarithmic and quadratic regression models are tested and it is decided that the most appropriate model is linear regression model.

\section{CASE STUDY AREA}

Kocaeli in which the study area is located lies between $29^{\circ} 22^{\prime}-30^{\circ} 21^{\prime}$ 'east and $40^{\circ} 31^{\prime}-$ $41^{\circ} 13^{\prime}$ north in the Çatalca-Kocaeli section of the Marmara Region. The surface area of Kocaeli is $3505 \mathrm{~km}^{2}$. It is located on the crossroad of an important road connecting Asia 
and Europe. Izmit Gulf which a natural harbor, is a busy sea route. Kocaeli is one of the major industrial cities of Turkey with its population of 1.8 million, its important industrial facilities and its developed economic structure (http://www.kocaeli.gov.tr/il-brifingi). In addition, Kocaeli is located on the North Anatolian Fault and the city suffered severe financial and moral losses due to the Marmara Earthquake (1999). The Marmara Earthquake is a milestone in terms of construction and urbanization. Many new laws have been regulated to accelerate efforts to reduce and prevent disaster damages since then. As a result various urban regeneration projects have been achieved and new projects are being continued in Turkey, especially in Kocaeli.

Erenler Cedit Houses, selected as a study area, is located within the First Urban Regeneration Area in Kocaeli (Fig.1). Erenler Cedit Houses are built on an area of 44.173 $\mathrm{m}^{2}$ at a distance of $3 \mathrm{~km}$ from the city center and project has 17 blocks of 588 apartments. There are 4 different types of apartments in the project. The project was completed in 2009 (http://www.kentkonut.com.tr/tr/icerikdetay/19/10/2009-yili-faaliyet-raporu.aspx).
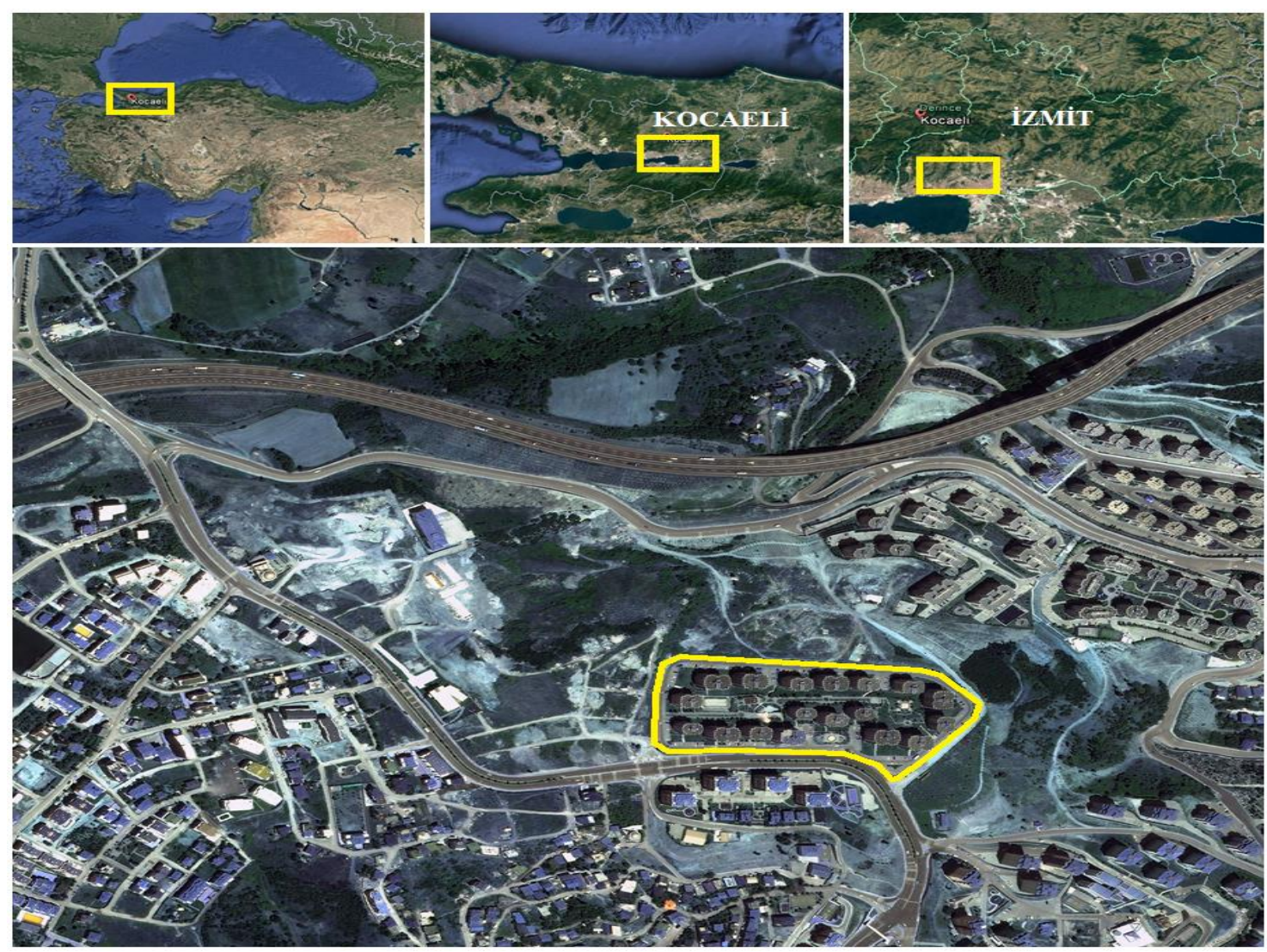

Figure 1. Study area highlighted with yellow line (taken from Google Earth).

The data of before and after Erenler Cedit project area are obtained from Kocaeli Metropolitan Municipality and Kent-Konut Inc. The main materials of the study are the $1 / 1000$ scale pre-regeneration base maps, public improvements and information about the proprietors. The size of the area was a total of 45.379,22 $\mathrm{m} 2$, consisting of 128 parcels before the project. There were a total of 80 owners two of who are Kocaeli Metropolitan Municipality and Treasury of Finance. Also, there were a total of 25 buildings. The construction permission was limited to three-storey before the urban transformation in the area. 


\section{GEOGRAPHIC INFORMATION SYSTEM OF ERENLER CEDIT URBAN REGENERATION AREA}

The base maps, zoning information, parcels and their sizes in the area which are obtained from Kocaeli Metropolitan Municipality are edited in CAD software. Thus, information of the urban transformation project is made to be usable in ArcGIS without any data loss. The parcel numbers, names of the owners, amount of their shares before the project, the qualification of the parcels after the regeneration, the worth which were received by owners are edited in attribute tables. The tables are transferred to ArcGIS, and related with the spatial data to query and analysis. The relational database is designed as manyto-many (m: $n$ ) due to the existence of multiple shareholders in multiple parcels [10]. Many-to-many (m: $\mathrm{n}$ ) relationship enables to query by switching between the tables used in the database [11]. It is given an ID number (PID) for each parcel to relate every shareholder in the parcels. Also, it is given another ID number (MID) for each shareholder to relate them each one or more parcels which are owned.

The parcel layer and attribute table which include the percent and quantities of the owners are combined in order to query in the database. The ID numbers (PID) for each parcel are defined as 'the primary key' and the relation between all of the shareholders on one parcel or all the parcels which belong to one owner are defined. In addition, another attribute table was created by summing the percent of parcel amounts of each of the owners.

In the other step of the study, the worth which is received by owners for their shares is arranged in another attribute table. The table is associated with an attribute table in which the share quantities of by selecting the MID as common column. In this table " 1 " represents cash payment; "2", "3", "4" and "5" represent types of houses which were given to the owners.

\section{QUERIES AND ANALYSIS OF THE SALES AND EXCHANGE TRENDS OF OWNERS}

As a result of the first query on "Erenler Cedit Urban Transformation GIS", it is revealed that 78 private property owners have $39302.22 \mathrm{~m}^{2}$, and public property including Kocaeli Metropolitan Municipality and Treasury of Finance has $6077.00 \mathrm{~m}^{2}$ in the study area. It is seen that the smallest total area corresponding to the shares is $10 \mathrm{~m}^{2}$ and the largest total area is $2941 \mathrm{~m}^{2}$ when 78 private property owners are sorted. It is grouped in order to be able to evaluate the sales and exchange trends of the owners according to their land sizes (Fig.2).

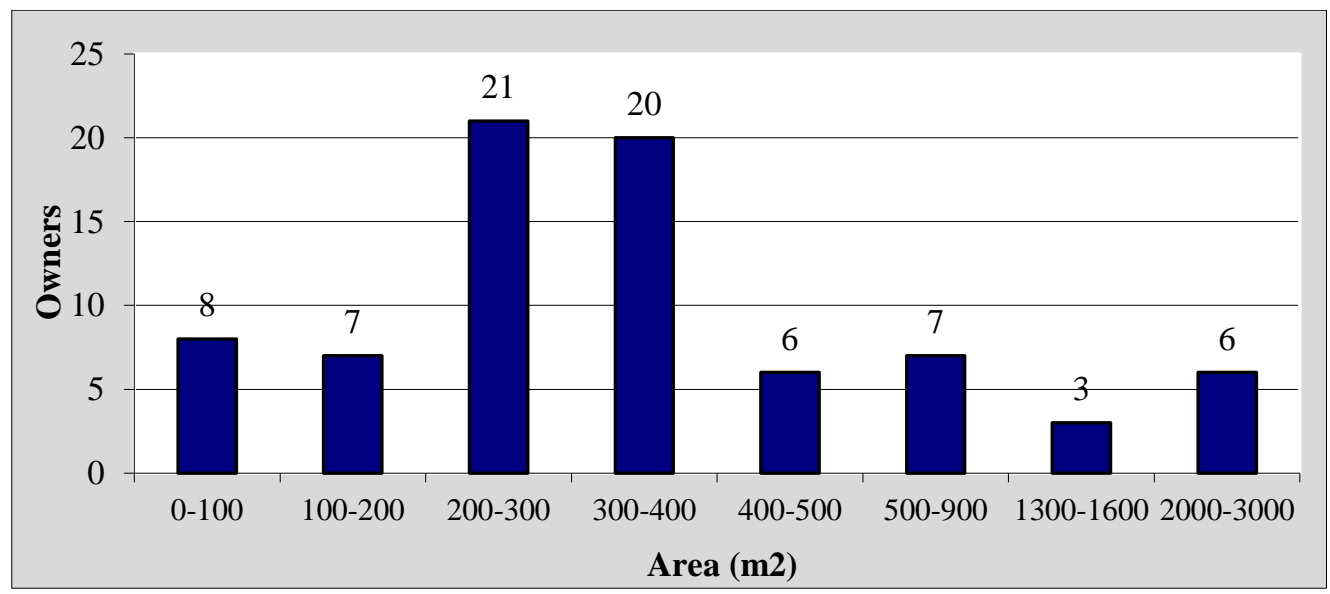

Figure 2. The distribution of private property owners 
As a result of query for all of the private property owners, it is observed that $72 \%$ of owners have preferred to sell their shares while $28 \%$ have preferred to receive house/houses to exchange for shares. It is interpreted that the owners who prefer to take cash payment are defined as "Sale", and the owners who prefer to receive house/ houses are defined as "Exchange" in the study.

The several queries to determine the trend of the sale or exchange for each defined owner groups based on land sizes in the geographic information system are shown in Fig.3 [12].

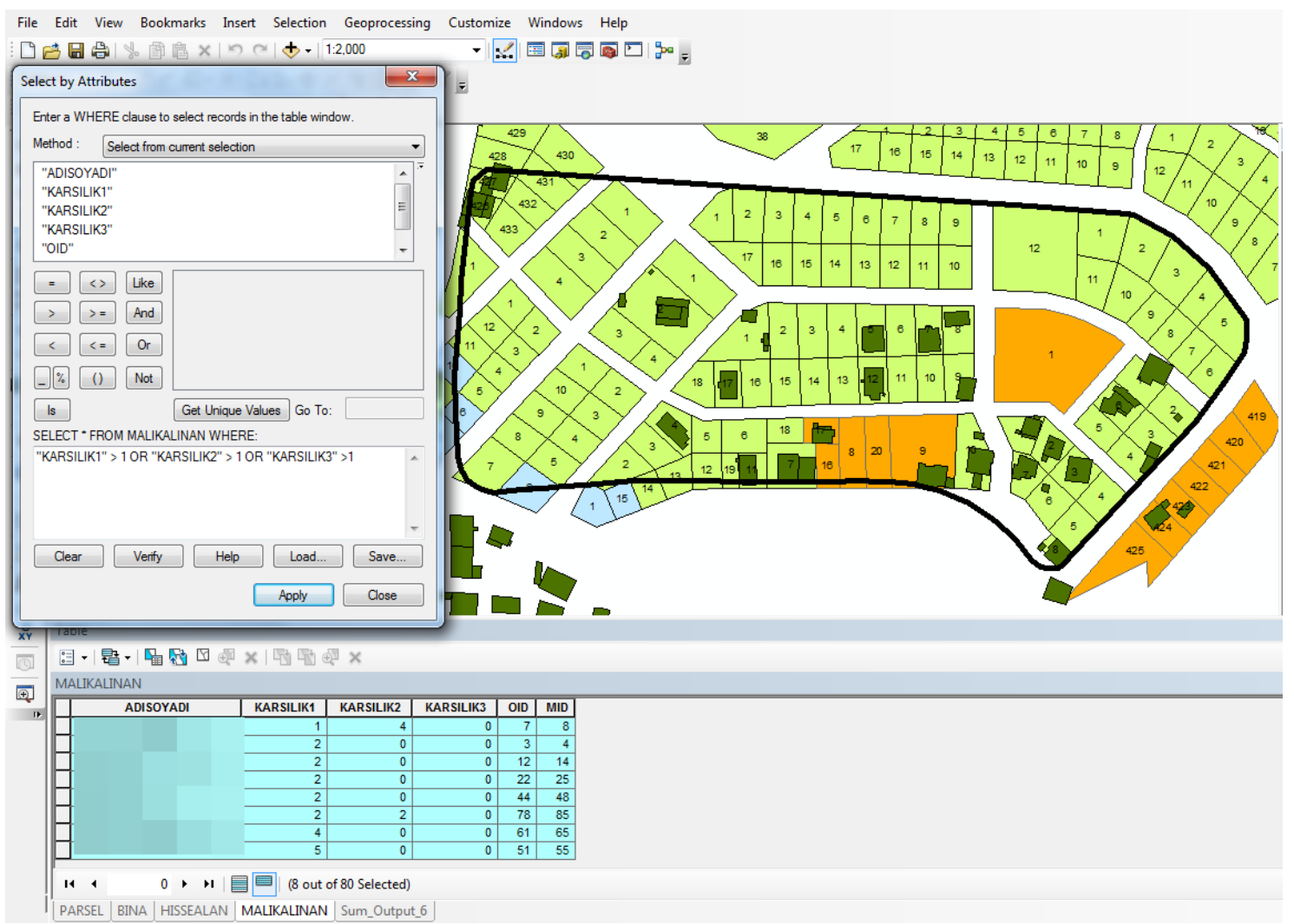

Figure 3. An example of a query for "Exchange"

The results of queries are summarized in Table1.

Table 1. Sales and exchange preferences according to the total shares of the owners

\begin{tabular}{|c|c|c|c|c|c|c|}
\hline $\begin{array}{c}\text { GROUPS } \\
(\mathbf{m} 2)\end{array}$ & $\begin{array}{c}\text { AVERAGE } \\
\text { AREA } \\
(\mathbf{m} 2)\end{array}$ & SALE & $\begin{array}{c}\text { SALE } \\
(\boldsymbol{\%})\end{array}$ & EXCHANGE & $\begin{array}{c}\text { EXCHANGE } \\
(\boldsymbol{\%})\end{array}$ & TOTAL \\
\hline $\mathbf{0 - 1 0 0}$ & 33 & 8 & 100 & 0 & 0 & 8 \\
\hline $\mathbf{1 0 0 - 2 0 0}$ & 132.7 & 6 & 86 & 1 & 14 & 7 \\
\hline $\mathbf{2 0 0 - 3 0 0}$ & 264.5 & 14 & 67 & 7 & 33 & 21 \\
\hline $\mathbf{3 0 0 - 4 0 0}$ & 335 & 12 & 60 & 8 & 40 & 20 \\
\hline $\mathbf{4 0 0 - 5 0 0}$ & 427.2 & 5 & 83 & 1 & 17 & 6 \\
\hline $\mathbf{5 0 0 - 9 0 0}$ & 624.2 & 6 & 86 & 1 & 14 & 7 \\
\hline $\mathbf{1 3 0 0 - 1 6 0 0}$ & 1444.5 & 2 & 67 & 1 & 33 & 3 \\
\hline $\mathbf{2 0 0 0 - 3 0 0 0}$ & 2416 & 3 & 50 & 3 & 50 & 6 \\
\hline & & $\mathbf{5 6}$ & $\mathbf{\% 7 2}$ & $\mathbf{2 2}$ & $\mathbf{\% 2 8}$ & $\mathbf{7 8}$ \\
\hline
\end{tabular}


The relationship between the land quantities and the exchange tendency is revealed by using Regression Analysis. Linear (eq.1), Quadratic (eq.2) and Logarithmic (eq.3) Regression Models are tested respectively.

$$
\begin{aligned}
& y=a+b x \\
& y=a+b x+c x^{2} \\
& y=a x^{b}
\end{aligned}
$$

It is observed that the logarithmic regression model is not appropriate for this type set of data (eq.3). In the quadratic regression model given above it is been comprehended that c parameter is not significant (eq.2). Therefore, it is decided that the most appropriate model is Linear Regression Model (eq.1)

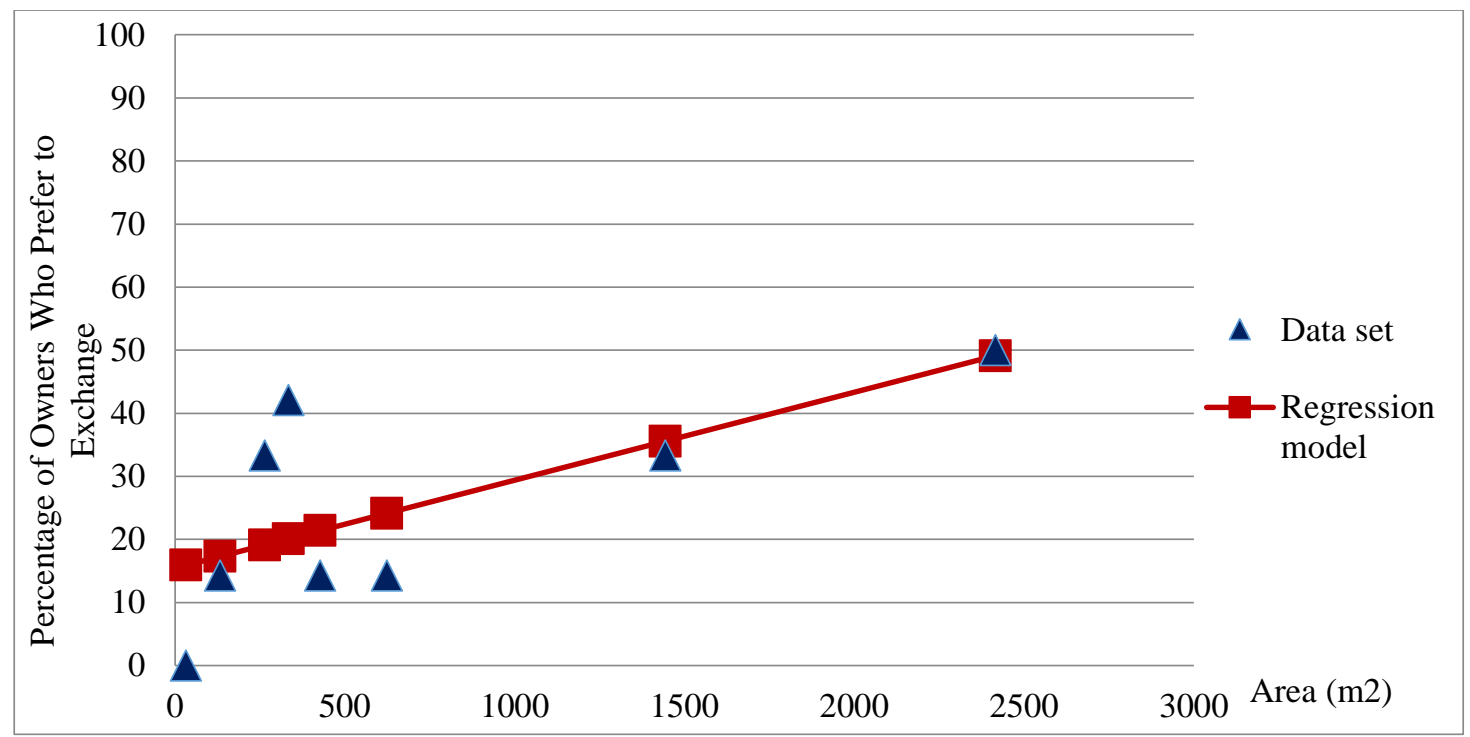

Figure 4. Linear regression model

The correlation coefficient between the land sizes and exchange preferences is calculated as $r=0.68$, least mean error $m_{0}= \pm 0.13(13 \%)$ in the linear regression model.

\section{CONCLUSION}

- Every urban transformation project has its own unique consequences. It is important to identify the advantages and disadvantages of each regeneration project in order for following projects to be accomplished well. This is usually possible with GIS.

- The data obtained from Geographic Information Systems can be analyzed with various methods and models. Some regression models are tried in the study.

- One of the most important principles in urban transformation is the protection of property relations in the region. When all the owners in the project are examined, it is seen that $28 \%$ of them preferred to exchange. Therefore, it can be referred that the example of Erenler Cedit could not protect the private property entirely. However, when the linear regression model is examined, it is seen that the owners of less than $200 \mathrm{~m}^{2}$ area did not tend to exchange. This is an expected behavior. On the other hand, it seems that there is a tendency to exchange for the owners of more than $200 \mathrm{~m}^{2}$ area. When the all data set is analyzed by linear regression model, a correlation coefficient $r=0.68$ is calculated for exchange preferences 
based on land sizes. Finally, it can be said that correlation coefficient for the project is strong and sufficient. However, it is expected that the correlation is stronger for urban transformation projects which property can be protected efficiently.

- There could be several reasons why better results could not be got in terms of protection of property rights in the project: Erenler Cedit urban transformation project is one of the first projects in Kocaeli. Therefore, the fact that the local people did not have any idea about urban transformation at that time may have increased their sale choices. Rough topography and difficulties of transportation before the regeneration also may have reduced the interest to settle down in the region. Also, 1999 Marmara Earthquake may have reduced the desire local people to live in Kocaeli. Further, living ones in Kocaeli may have not preferred highrised buildings.

Despite all mentioned negative reasons, it can be said that the private property rights were protected at a good level in this project.

\section{REFERENCES}

[1] Roberts, P. \& Sykes, H., The Evolution, Definition and Purpose of Urban Regeneration, Urban Regeneration: A Handbook, London, Thousand Oaks, New Delhi: Sage Publications, 2000.

[2] Şişman, A. \& Kibaroğlu, D., Dünyada ve Türkiye'de Kentsel Dönüşüm Uygulamaları, TMMOB Harita ve Kadastro Mühendisleri Odas 12. Türkiye Harita Bilimsel ve Teknik Kurultay1, Ankara, Turkey, 2009.

[3] Akkar, Z. M., Kentsel Dönüşüm Üzerine Batı' daki Kavramlar, Tanımlar, Süreçler ve Türkiye, Planlama, TMMOB Şehir Plancıları Odası Yayını, vol: 2, pp: 29, 2006.

[4] Erkan, H., Kadastro Bilgisi- Güncellenmiş Yeni Baskı, TMMOB Harita ve Kadastro Mühendisleri Odas1, Ankara, Turkey, 2011.

[5] Tekeli, I., Modernite Aşılırken Kent Planlaması, İmge Kitabevi, Ankara, Turkey, 2001.

[6] Yasin, M., Kentsel Dönüşüm Uygulamalarının Hukuki Boyutu, Türkiye Barolar Birliği Dergisi, Turkey, vol: 60, pp 105-137, 2005.

[7] Şimşek, S., Mülkiyet Hakkının Kapsamı, Sınırlandırma Karşılaştırmalı Bir Analiz Nedenleri ve Şartları Açısından 1982 Anayasası ve Avrupa İnsan Hakları Sözleşmesi, Türkiye Barolar Birliği Dergisi, Turkey, vol: 91, pp 181-228, 2010.

[8] Sönmez, N. K. \& Sarı, M., Coğrafi Bilgi Sistemleri Temel Esasları ve Uygulama Alanları, Derim, Turkey, Cilt: 21, vol: 1, 2004.

[9] Yomralığlu, T., Coğrafi Bilgi Sistemi Temel Kavramlar ve Uygulamalar, İstanbul, Turkey, 2000.

[10] Jackson, D. \& Wang, M., Modeling the Many-To-Many Relationship Using MultiValued Foreign Keys, International Association for Computer Information Systems, Issues in Information Systems, vol: 6, No. 1, 2005. 
[11] Caffrey, M., Modeling and Accessing Relational Data, Oracle Magazine, November -December, 2011.

[12] Aslan, B. \& İnce, C. D. \& Bostan, S., Kentsel Dönüşüm Uygulamalarında Mülkiyet Değişiminin Coğrafi Bilgi Sistemleri ile Analizi: Kocaeli-Erenler Cedit Örneği, 6. Uzaktan Algılama ve CBS Sempozyumu, Adana, Turkey, 2016. 